\title{
p53, bcl-2, and nm23 Expressions in Serous Ovarian Tumors: Correlation with the Clinical and Histopathological Parameters
}

\author{
Seröz Over Tümörlerinde p53, bcl-2 ve nm23 Ekspresyonu: \\ Klinik ve Histopatolojik Parametreler ile İlişkisi
}

\author{
Deniz ARIK' ${ }^{1}$, Sezer KULAÇOĞLU² \\ Department of Pathology, ${ }^{1}$ M.H. Karaman State Hospital, KARAMAN, TURKEY, ${ }^{2}$ Ankara Numune Education and Research Hospital, ANKARA, TURKEY
}

\begin{abstract}
Objective: We studied p53, bcl-2, and nm 23 expressions in serous benign, borderline and malignant tumors of the ovary. Our aim was to determine the association between these expressions and some clinical (patient age, tumor dimension, omenthal involvement, the presence of malignant cells in peritoneal fluid) and histopathological (grade, number of mitosis, nuclear pleomorphism, structural pattern) parameters in malignant serous tumors.
\end{abstract}

Material and Method: A total of 71 tumors including 29 benign, 14 borderline, and 28 malignant ovarian serous tumors were included in the study. p53, bcl-2, and nm23 immunohistochemical staining was performed on the paraffin blocks. The results were scored as $(+),(++)$ and $(+++)$ according to the extent of staining.

Results: There was no staining for p53 in benign or borderline tumors. p53 was positive in $42.9 \%$ of malignant tumors. nm23 expression was revealed as $44.8 \%, 64.3 \%$ and $67.9 \%$ in benign, borderline and malignant tumors, respectively. Bcl-2 was positive in only $17.2 \%$ of benign, $35.7 \%$ of borderline and $25 \%$ of malignant tumors.

Conclusion: The p53 positivity detected only in serous carcinomas shows its role in carcinogenesis. p53 was expressed at a significantly higher rate in advanced stage carcinomas $(\mathrm{p}=0.031)$. $\mathrm{nm} 23$ expression in benign, borderline and malignant tumors was not significantly different. nm 23 positivity was higher in advanced stage carcinomas $(\mathrm{p}=0.032)$. This suggest that $\mathrm{nm} 23$ acts like an oncogene in ovarian carcinomas. There was no significant difference between the groups in terms of bcl-2 expression.

Key Words: Ovary, Neoplasms, Serous neoplasms, p53, bcl-2, nm23
ÖZ

Amaç: Çalışmamızda overin benign, borderline ve malign seröz tümörlerinde immünhistokimyasal olarak p53, bcl-2 ve nm23 ekspresyonun araştırılması, malign tümörlerde bu ekspresyonların evre, yaş, tümör boyutu, omentum tutulumu, periton sıvısında malign hücre varlığı gibi özelliklerle ve bazı histopatolojik parametrelerle (grade, mitoz sayısı, nükleer pleomorfizm, yapısal patern) ilişkisinin belirlenmesi amaçland.

Gereç ve Yöntem: Çalışmaya 29 benign, 14 borderline, 28 malign seröz tümör olmak üzere toplam 71 olgu alındı. Parafin blokta p53, bcl-2 ve nm23 ile immünhistokimyasal çalışma yapıldı. Sonuçlar boyanma yaygınlığına göre $(+),(++),(+++)$ şeklinde skorlandı.

Bulgular: Benign ve borderline tümörlerde p53 ile boyanma yoktu. Karsinomlarda ise \%42,9 oranında ekspresyon saptand. nm23 ekspresyonu, benign, borderline ve malign tümörlerde sırası ile $\% 44,8, \% 64,3$ ve $\% 67,9$ olarak bulundu. Bcl-2 ekspresyonu benign tümörlerde $\% 17,2$, borderline tümörlerde $\% 35,7$, karsinomlarda $\% 25$ idi.

Sonuç: p53'ün overin sadece seröz karsinomlarında pozitif bulunması karsinogenezde rol aldığını göstermektedir. p53 ileri evre olgularda daha fazla eksprese olmaktadır $(\mathrm{p}=0,031)$. Nm23'ün benign, borderline ve malign tümörlerde ekspresyon oranları istatistiksel olarak farklı değildir. Karsinom olgularında ise ileri evrede nm23 pozitifliği anlamlı derecede yüksektir $(\mathrm{p}=0,032)$. Bu durum nm23'ün over karsinomlarında bir onkogen gibi davrandığını düşündürmüştür. Bcl-2 ekspresyonu açısından gruplar arasında anlamlı fark yoktur.

Anahtar Sözcükler: Over, Neoplazmlar, Seröz neoplazmlar, p53, bcl-2, nm23 


\section{INTRODUCTION}

Ovarian carcinomas make up $4 \%$ of cancers seen in females and they are the gynecological cancers that lead to the most deaths (1). They are seen especially in Scandinavian countries among developed countries and are relatively less common in Japan and developing countries (2). The lack of symptoms in the early period leads to most cases being diagnosed at advanced stages.

Serous tumors make up approximately one-fourth of all ovarian tumors. Despite the data obtained regarding pathogenesis, the precursor lesions of ovarian carcinoma are not clearly known. The lack of benign-appearing areas in serous carcinomas indicates that these tumors develop directly from the epithelium without a precursor lesion. Some authors have stated that there may be a rapid adenomacarcinoma sequence in the development of the tumors and that precursor lesions may not be seen for that reason (3). There is no generally accepted grading system for ovarian carcinomas. The dual grading system suggested by Malpica for serous carcinomas that has been said to overlap with the dualistic carcinogenesis model postulated by Kurman has been discussed recently (4). The most commonly used system is the universal grading system of ShimizuSilverberg. The growth pattern, number of mitoses and nuclear pleomorphism are scored and graded to increase the inter-observer consistency in this system (5).

The p53 tumor suppressor gene is active at a cell cycle control point and plays a role in providing a response to DNA damage $(6,7)$. Although it is generally accepted that p53 mutations, shown to affect the prognosis in many cancers, are an unfavorable prognostic factors in ovarian carcinoma, there are also reports that they have no effect on the prognosis $(8,9)$. The mean rate of reported p53 positivity is $51 \%$ in serous carcinomas and $1 \%$ in borderline and benign tumors (10).

The $\mathrm{Bcl}-2$ gene is a proto-oncogene located on the 18th chromosome. The Bcl-2 gene product is an integral membrane protein located in the internal membranes of mitochondria and is named the bcl-2 protein. The $\mathrm{Bcl}-$ 2 gene plays an important role in programmed cell death (11). Mano et al. have reported a bcl-2 expression of $25 \%$ in stage I and $44 \%$ in stage 2 cases and postulated that the response to chemotherapy decreased with increased expression (12). Chan states that bcl-2 expression decreases with a shift from benign tumors to malignant tumors (13). Geisler has claimed that the p53 and bcl- 2 combination is an independent parameter of survival. Cases that are p53 negative and bcl-2 positive have the best prognosis (14). The p53 mutant protein can inhibit the production of the bcl-2 protein and mRNA. This indicates that the reason for bcl-2 downregulation in malignant tumors may be the inhibitory effect of p53 (15).

$\mathrm{nm} 23$ is located on codon 21.3 of the long arm of chromosome 17 in humans. It has first been defined by Steeg in 1988 as the metastasis suppressor gene that codes the nucleotide diphosphate (NDP) kinase protein (16). It is claimed that $\mathrm{nm} 23$ suppresses metastasis but its mechanism of action in metastasis suppression has not been clearly demonstrated. It has been reported to correlate with a predicted decreased metastatic potential by taking into account the decreased $\mathrm{nm} 23$ expression in breast, gastric, cervical cancers, hepatocellular carcinoma and malignant melanoma and features such as survival, the presence of lymph node metastasis and little differentiation (17). There are articles stating contradicting results on the effect of $n m 23$ on ovarian carcinoma prognosis $(18,19)$.

The aim of our study was to investigate $\mathrm{p} 53, \mathrm{bcl}-2$ and $\mathrm{nm} 23$ expression immunohistochemically in benign, borderline and malignant serous tumors of the ovary and also to determine the association between these "markers" and features such as age, tumor size, stage, omentum involvement and the presence of malignant cells in the peritoneum and some histopathological parameters (grade, number of mitoses, nuclear pleomorphism, structural pattern).

\section{MATERIAL and METHOD}

We included a total of 71 serous ovarian tumors diagnosed at the Ankara Numune Training and Research Hospital Department of Pathology in this study. The tumors were grouped as malignant, borderline and benign. Carcinoma cases were evaluated for stage, age, tumor size, grade, histopathological features (structural pattern, number of mitoses, nuclear pleomorphism), omentum involvement and the presence of malignant cells in peritoneal fluid. The Shimizu-Silverberg system was used for tumor grading as follows: 1 point if the dominant growth pattern was glandular, 2 points if papillary and 3 points if solid. The cytological atypia was graded according to severity as 1, 2 or 3. Mitotic figures were counted in 10 high-power fields and 9 or less was given a score of 1,10-24 2 and 25 or more 3 . The sum of these scores were evaluated as tumor grade I if 3 to 5 , II if 6 or 7 and III if 8 or 9 in number. The age of the cases and tumor size were determined in benign and borderline tumors.

The paraffin block that best reflected the morphology among the tumor samples was chosen and sections $5 \mu \mathrm{m}$ thick prepared. The streptavidin-peroxidase method was used 
for the immunohistochemical evaluation. The endogenous peroxidase activity was blocked by incubation with hydrogen peroxide for 10-15 minutes following deparaffinization and rehydration. The tissues were treated with primary prediluted monoclonal antibody. The markers used were Ab-5, clone DO-7 (Neomarkers) for p53, Ab-1 (Neomarkers) for nm23 and bcl-2a Ab-1, clone 100/D5 (Neomarkers) for bcl-2. The sections were washed and incubated for 10 minutes in biotinylated goat antipolyvalent conjugate. This procedure was repeated for $10 \mathrm{~min}$ with the streptavidin-peroxidase complex. Chromogen was applied and contrast staining was obtained with Mayers hematoxylin. Glycerol was used to cover. The control materials were larynx squamous cell carcinoma for $\mathrm{p} 53$, colon adenocarcinoma for $\mathrm{nm} 23$ and tonsilla palatina for bcl-2.

We evaluated tumor cell cytoplasmic membrane staining and cytoplasmic staining for bcl-2, nuclear staining for $\mathrm{p} 53$, and cytoplasmicstaining for $n m 23$ during immunohistochemical evaluation. The grading was (+) for $1-10 \%$ staining, $(++)$ for $10-50 \%$ staining and $(+++)$ for more than $50 \%$ staining. The statistical analysis was performed using these staining results. The two groups were then separated as negative and positive and the statistical difference of the parameters between the groups evaluated.

The data obtained were analyzed with the "Mann-Whitney U" test, ANOVA, Kruskal-Wallis, Chi square, and Spearman's correlation test during statistical analysis. A $p$ value $<0.05$ was considered statistically significant for all tests.

\section{RESULTS}

The distribution of the serous tumors was 29 benign, 14 borderline and 28 malignant. The mean age was 58.6 for serous carcinomas, 50.3 for benign serous tumors and 48.0 for borderline serous tumors. The mean tumor size was 10.2 for serous carcinomas and 17.2 and $15.0 \mathrm{~cm}$ for the benign and borderline serous tumors, respectively. Table I summarizes the clinical and histopathological features of serous carcinomas.

p53 expression was not observed in benign or borderline serous tumors (Figure 1). The p53 expression rate in serous carcinomas was $42.9 \%(\mathrm{p}=0.00)$ (Table II). We found no correlation between tumor stage and p53 staining diffuseness $(\mathrm{p}=0.765)$. However, $\mathrm{p} 53$ positivity was significantly higher in the advanced stages when the cases were groups as early and late stage $(p=0.031)$. There was no relationship between $\mathrm{p} 53$ staining diffuseness and grade in carcinomas $(\mathrm{p}=0.169)$.

The mean age was 55.5 and 62.7 for the cases with and without $\mathrm{p} 53$ expression, respectively. There was no difference
Table I: Clinical and histopathological features in serous carcinoma cases

\begin{tabular}{|c|c|c|c|}
\hline & & $\mathbf{n}$ & $\%$ \\
\hline \multirow{2}{*}{ Bilaterality } & unilateral & 5 & 17.9 \\
\hline & bilateral & 23 & 82.1 \\
\hline \multirow{2}{*}{$\begin{array}{l}\text { Omentum } \\
\text { involvement }\end{array}$} & - & 6 & 21.4 \\
\hline & + & 22 & 78.6 \\
\hline \multirow{2}{*}{$\begin{array}{l}\text { Malignant cells in } \\
\text { peritoneal fluid }\end{array}$} & - & 3 & 10.7 \\
\hline & + & 25 & 89.3 \\
\hline \multirow{4}{*}{ Stage } & I & 3 & 10.7 \\
\hline & II & 3 & 10.7 \\
\hline & III & 11 & 39.3 \\
\hline & IV & 11 & 39.3 \\
\hline \multirow{3}{*}{ Grade } & I & 9 & 32.1 \\
\hline & II & 12 & 42.9 \\
\hline & III & 7 & 25.0 \\
\hline \multirow{3}{*}{$\begin{array}{l}\text { Tumor growth } \\
\text { pattern }\end{array}$} & glandular & 9 & 32.1 \\
\hline & papillary & 12 & 42.9 \\
\hline & solid & 7 & 25.0 \\
\hline \multirow{3}{*}{ Pleomorphism } & mild & 4 & 14.3 \\
\hline & moderate & 13 & 46.4 \\
\hline & marked & 11 & 39.3 \\
\hline \multirow{3}{*}{$\begin{array}{l}\text { Number of mitoses } \\
(10 \mathrm{HPF})\end{array}$} & $\leq 9$ & 10 & 35.7 \\
\hline & $10-24$ & 10 & 35.7 \\
\hline & $\geq 25$ & 8 & 28.6 \\
\hline & Total & 28 & 100.0 \\
\hline
\end{tabular}

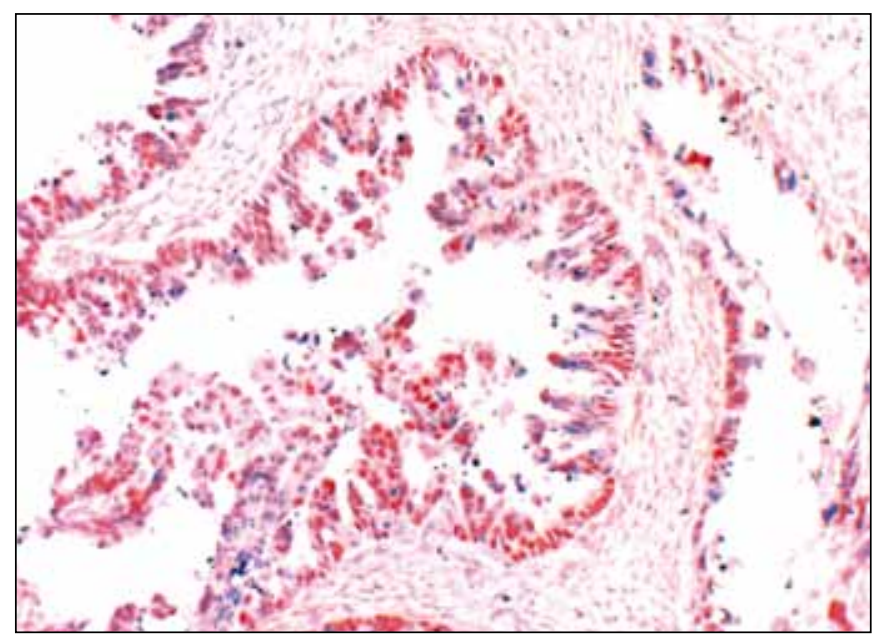

Figure 1: Serous carcinoma (p53; x100). 
Table II: p53, bcl-2 and nm23 staining results in serous tumors

\begin{tabular}{|c|c|c|c|c|c|c|c|c|c|c|c|c|}
\hline & \multicolumn{4}{|c|}{ p53 } & \multicolumn{2}{|c|}{ bcl-2 } & \multicolumn{4}{|c|}{$\mathrm{nm} 23$} & \multirow{2}{*}{ Total } \\
\hline & & - & + & ++ & +++ & - & + & - & + & ++ & +++ & \\
\hline \multirow{2}{*}{ Serous carcinoma } & $\mathrm{n}$ & 16 & 10 & 1 & 1 & 21 & 7 & 9 & 15 & 3 & 1 & 28 \\
\hline & $\%$ & 57.1 & 35.7 & 3.6 & 3.6 & 75.0 & 25.0 & 32.1 & 53.6 & 10.7 & 3.6 & 100.0 \\
\hline \multirow{2}{*}{$\begin{array}{l}\text { Borderline serous } \\
\text { tumor }\end{array}$} & $\mathrm{n}$ & 14 & 0 & 0 & 0 & 9 & 5 & 5 & 3 & 2 & 4 & 14 \\
\hline & $\%$ & 100.0 & 0 & 0 & 0 & 64.3 & 35.7 & 35.7 & 21.4 & 14.3 & 28.6 & 100.0 \\
\hline \multirow{2}{*}{$\begin{array}{l}\text { Benign serous } \\
\text { tumor }\end{array}$} & $\mathrm{n}$ & 29 & 0 & 0 & 0 & 24 & 5 & 16 & 10 & 1 & 2 & 29 \\
\hline & $\%$ & 100.0 & 0 & 0 & 0 & 82.8 & 17.2 & 55.2 & 34.5 & 3.4 & 6.9 & 100.0 \\
\hline
\end{tabular}

between the groups with and without p53 expression for age, tumor size, bilaterality, omentum involvement, the presence of malignant cells in the peritoneal fluid and histopathological parameters (tumor development pattern, pleomorphism, number of mitoses).

Bcl-2 expression was $17.2 \%$ in benign serous tumors, $35.7 \%$ in borderline serous tumors and $25 \%$ in serous carcinomas (Figure 2,3). We found no $(++)$ or $(+++)$ staining in the cases (Table II). The bcl-2 expression was 1 to $10 \%$ in all (+) cases. Five of the $7 \mathrm{bcl}-2$ positive serous carcinoma cases were stage IV. Advanced stages had higher rates of bcl-2 expression but this was not statistically significant $(\mathrm{p}=0.168)$. The bcl-2 expression rate was $33.3 \%$ in grade I and $33.3 \%$ in grade II cases while we found no staining in grade III cases. There was no relationship between bcl-2 expression and grade in carcinomas. Omentum involvement and malignant cells in the peritoneum were present in 7 cases with bcl-2 expression but we found no significant difference between this group and the group with no bcl2 expression $(\mathrm{p}=0.288)$. There was no difference between the bcl-2 negative and positive groups for age, tumor size, bilaterality or histopathological parameters (tumor growth pattern, pleomorphism, number of mitoses).

The nm23 expression frequency was $44.8 \%, 64.3 \%$, and $67.9 \%$ respectively in benign, borderline and malignant serous tumors (Figure 4,5). The difference between the groups was not statistically significant $(\mathrm{p}=0.192)$. However, nm23 expression was significantly higher in borderline tumors than benign tumors in terms of staining diffuseness $(\mathrm{p}=0.012)$. Although staining diffuseness was thought to be increased in advanced stage cases in carcinomas, we found no statistically significant difference $(\mathrm{p}=0.116)$. Evaluating $\mathrm{nm} 23$ positivity showed that advanced stage cases expressed $\mathrm{nm} 23$ at a statistically significantly higher rate $(\mathrm{p}=0.032)$. The $\mathrm{nm} 23$ expression rate was $66.7 \%, 58.3 \%$ and $85.7 \%$ for Grade I, II and III tumors, respectively. We found no significant relationship between $\mathrm{nm} 23$ and grade $(\mathrm{p}=0.502)$. The $\mathrm{nm} 23$ expression was significantly higher in serous carcinoma cases with omentum involvement

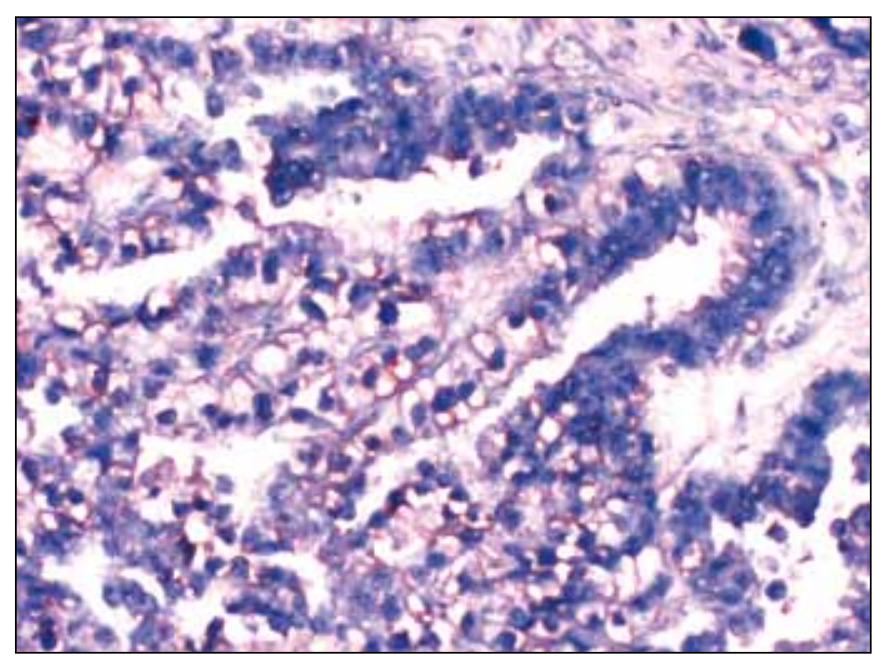

Figure 2: Grade III serous carcinoma (bcl-2; x400).

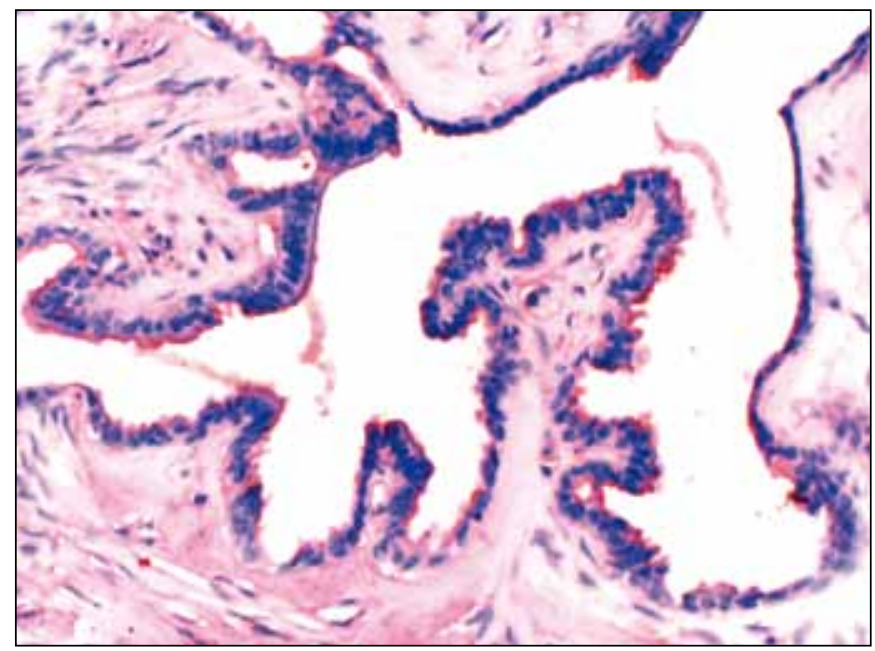

Figure 3: Benign serous tumor (bcl-2; x200). 


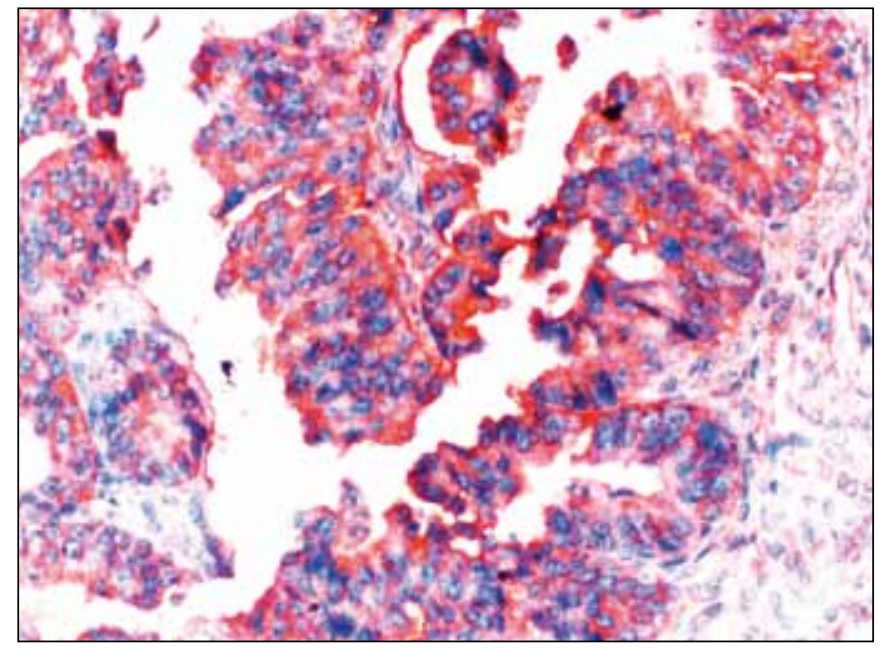

Figure 4: Grade I serous carcinoma (nm23; x400).

$(\mathrm{p}=0.041)$. There was no difference for age, tumor size, bilaterality, the presence of malignant cells in the peritoneal fluid and histopathological parameters (tumor development pattern, pleomorphism, number of mitoses) between the ()$,(+),(++)$, and $(+++) \mathrm{nm} 23$ expression groups in serous carcinomas. Classifying into two groups as $\mathrm{nm} 23$-negative and -positive showed less nm23 positivity in cases with a glandular growth pattern than those with a papillary and solid growth pattern $(\mathrm{p}=0.01)$.

We found a positive correlation between $\mathrm{nm} 23$ and bcl2 in serous carcinomas $(\mathrm{p}=0.04)$. $\mathrm{nm} 23$ expression was significantly more frequent in cases with Bcl-2 expression. We found no correlation between $\mathrm{p} 53$ and bcl-2 ( $\mathrm{p}=0.86)$. We thought there was an inverse correlation between p53 and nm 23 but could not demonstrate this on statistical analysis $(\mathrm{p}=0.579)$.

\section{DISCUSSION}

Ovarian carcinomas make up $90 \%$ of malignant tumors of the ovary (1). The global 5-year survival of ovarian carcinoma cases ranges from $32 \%$ to $46 \%$. The generally accepted independent prognostic factor for ovarian carcinomas is the FIGO stage (20). The serous carcinomas in our study were diagnosed at stage I in $10.7 \%$, stage II in $10.7 \%$, stage III in $39.3 \%$ and stage IV in $39.3 \%$. This means that approximately one-fifth of the cases were early stage (stage I and II) while four-fifths were late stage (stage III and IV).

p53 is the most common genetic change in cancer. Kmet et al. has reported p53 overexpression at a mean rate of 51\% in a total of 6839 ovarian carcinoma cases in their review of studies in the literature (10). The results obtained with immunohistochemical methods are known to change

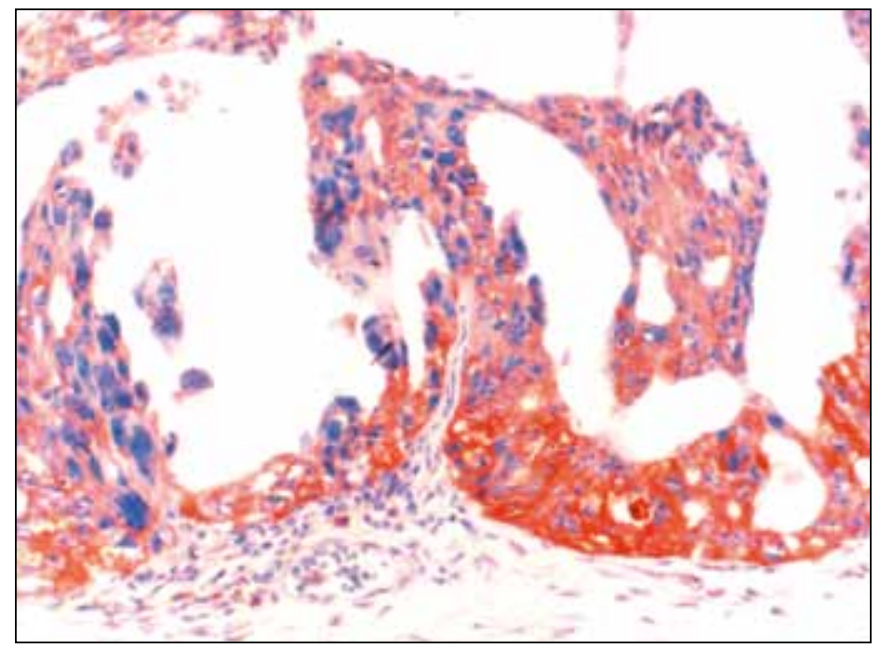

Figure 5: Borderline serous tumor (nm23; x200).

according to the monoclonal antibody used. The most common antibodies used for p53 are DO-7 and PAb1801 monoclonal antibodies. These antibodies detect both "wild" type and mutant p53 protein. We used the p53 DO7 monoclonal antibody in our study and the results signify the p53 overexpression in cases with and without p53 mutations (eg. DNA repair process). It is necessary to use polymerase chain reaction (PCR) and SSCP (single-strand conformation polymorphism) techniques to specifically show a p53 mutation. Results obtained with these methods show a mutation rate of $51 \%$ in serous carcinomas (10). Schuijer and Berb state a p53 overexpression rate of $59 \%$ and mutation rate of $58 \%$ in serous carcinomas (21). The p53 expression results obtained with the immunohistochemical technique may not fully correlate with the results obtained through specific mutation analyses but the correlation between overexpression and mutation is statistically significant (22). There is $68 \%$ concordance between p53 mutation analyses and the immunohistochemistry results (23).

We found a p53 overexpression rate of $42.9 \%$ in our study. The literature reports positive results of $48.5 \%$ to $69 \%$ in studies using the p53 DO-7 antibody $(8,13,22,23)$. Our results are lower than the literature results on average. Many factors influence p53 study results. The different tissues used in different studies can give different results. The p53 antigen is reported to be better presented in fresh tissue studied by frozen section (22). The different enzymes used for staining and the microwave procedure can also have a marked effect on the staining results. Another reason for the different reported results is the different 'cut off' values used in the studies. 
Comparing the stage with p53 expression, Skirnisdottir et al. reported positivity rates of $17.4 \%$ in grade I, $47.8 \%$ in grade II and $34.8 \%$ in grade III cases in 106 ovarian carcinoma patients. High-grade tumors are reported to show significantly higher p53 expression than low-grade tumors (24). We found more p53 expression in grade II tumors in our study while grade III tumors showed less p53 expression than expected. We believe this is due to the low number of cases. The difference between the groups was not statistically significant $(\mathrm{p}=0.169)$.

Werness has reported that p53 expression does not show a correlation with clinicopathological parameters or the prognosis and that cases with p53 expression are older than those without, and that these tumors are of the serous histological subtype and high-grade tumors (8). The mean age was 55.5 in those with p53 expression and 62.7 in those without in our study. The difference was not significant $(\mathrm{p}=0.413)$.

A study on p53 expression in the normal ovary and ovarian tumors has found p53 expression in $43 \%$ of immunohistochemicallly normal ovary tissue, $18 \%$ in benign epithelial tumors, $19 \%$ in borderline tumors and $53 \%$ in carcinomas. Mutation analysis with PCR and SSCP in the same cases showed a p53 mutation rate of 55\% (13). Finding a higher rate of $\mathrm{p} 53$ in serous carcinomas is expected. The p53 expression distribution shows a larger number of $(+)$ results. However, Inoue has reported larger numbers of $(++)$ and $(+++)$ staining in a similar study (25).

A bcl-2 expression rate of $19-33 \%$ has been reported in ovarian carcinomas $(9,13,14,24,26)$. Chan has reported the bcl-2 expression positivity rate in normal ovary tissue and benign, borderline and malignant ovarian tumors as $79 \%$, $100 \%, 78 \%$ and $33 \%$, respectively. A significant decrease in bcl-2 expression from benign tumor to malignant tumors was reported (13). We found no difference in bcl2 expression between benign, borderline and malignant serous tumors in our study. Seven bcl-2 positive serous carcinomas out of 28 cases were distributed as stage 2 in 1 case, and stage 3 or 4 in 6 cases. The bcl-2 positivity was higher in advanced stage cases but grade evaluation showed that bcl-2 positive cases were grade 1 and 2 . We believe this discordance may be due to the low number of cases.

Studies on bcl-2 in ovarian carcinoma usually include p53 and evaluate the relationship with prognosis. There are only a few studies comparing histopathological and clinical parameters with bcl-2 expression. Sagarra et al. reports a bcl-2 expression rate of $8 \%$ in grade I carcinomas, $21 \%$ in grade II carcinomas and $24 \%$ in grade III carcinomas with bcl-2 positivity increasing as the grade increases (9). Chan et al. and Diebold et al. state that the bcl-2 expression decreases as the grade increases with statistical significance $(13,26)$. We found a bcl-2 expression rate of $33.3 \%$ in grade I cases, $33.3 \%$ in grade II cases and no staining in grade III cases. We did not find a significant difference between the histopathological and clinical parameters and bcl-2 expression on statistical studies.

Chan et al. has reported the lack or low levels of bcl-2 expression in an ovarian cancer with diffuse p53 expression. It was also reported that p53 was not found in tumors with high levels of bcl-2 expression (13). Our study results indicate an inverse correlation between $\mathrm{p} 53$ and bcl-2 but statistical evaluation did not demonstrate the correlation.

The role of nm23 in gynecological cancers is not clear. The $\mathrm{nm} 23$ expression has been reported to decrease in cases with lymph node metastasis and tumors with an aggressive course $(26,27)$. Schneider et al. has found $\mathrm{nm} 23$ expression in 12 of 26 serous carcinoma cases of which 9 were at an advanced stage and postulated that $\mathrm{nm} 23$ acts like an oncogene in addition to its potential antimetastatic effect and that it is expressed at a significantly higher level in advanced stage and aggressive tumors (28). Similarly, it is reported that high $\mathrm{nm} 23$ expression is correlated with the mortality rate and unfavorable clinical course (29). Other studies report that $\mathrm{nm} 23$ does not have prognostic value in ovarian carcinomas and is not associated with metastasis (30).

The $\mathrm{nm} 23$ expression rate was $67.9 \%$ in serous carcinomas, $64.3 \%$ in borderline serous tumors and $44.8 \%$ in benign serous tumors in our study. These rates are higher than in the literature. We found higher rates of $n m 23$ expression in carcinomas and borderline tumors than benign tumors, although not statistically significant $(\mathrm{p}=0.116)$. When we evaluated the results in two separate groups as positive and negative, we found that $84.2 \%$ of the $\mathrm{nm} 23$ positive cases and $66.2 \%$ of the negative cases were at an advanced stage ( $\mathrm{p}: 0.032$ ). This indicates that $\mathrm{nm} 23$ is expressed at a higher rate in advanced stage serous ovarian carcinoma cases in contrast to breast carcinoma and is acting like an oncogene. There are reports stating that $\mathrm{nm} 23$ is expressed in direct or inverse correlation with the malignancy potential. However, Schneider et al. has come up with a threshold pass theory (28) where it is stated that tumor malignancy is directly correlated with $\mathrm{nm} 23$ expression and that ovarian carcinomas are therefore in the same group as neuroblastomas and colon carcinomas (28). In addition to concurrence with the more malignant phenotype, $\mathrm{nm} 23$ also has an effect that decreases spread in these 
tumors. nm23 is therefore expressed when the threshold value for malignancy is passed by the tumor and is one of the mechanisms that will prevent cellular spread. This explains why $\mathrm{nm} 23$ is an indicator of better prognosis in slow growing tumors such as breast carcinoma. However, ovarian carcinomas show rapid tumor progression and the threshold value is passed quickly. nm23 expression seems to appear in the late stage of ovarian carcinogenesis (28).

No significant relationship was found when grade and $\mathrm{nm} 23$ expression were compared in serous carcinomas but we found that tumors with a glandular growth pattern showed significantly less expression than those with papillary and solid growth $(\mathrm{p}=0.01)$ when tumor growth pattern, one of the grading system parameters, was compared with the $\mathrm{nm} 23$ expression. We can therefore say that there is less $\mathrm{nm} 23$ expression in more differentiated tumors. The $\mathrm{nm} 23$ expression was not different between groups classified according to their degree of pleomorphism or frequency of mitotic activity. These findings with serous tumors support literature data that $\mathrm{nm} 23$ is expressed at a higher level in tumors with an aggressive phenotype, that the role of nm 23 in ovarian carcinomas is different than in breast carcinomas and that $\mathrm{nm} 23$ plays a tissue-specific role.

We found that serous carcinomas with p53 expression showed weak staining with $\mathrm{nm} 23$ which indicated an inverse relationship between $\mathrm{p} 53$ and $\mathrm{nm} 23$ but no statistical correlation could be demonstrated $(r=0.067, \mathrm{p}=0.579)$

In conclusion, $\mathrm{p} 53$ plays a role in the carcinogenesis of serous tumors and appears at the late stage. The lack of a difference in bcl-2 expression in benign, borderline and malignant tumors and the inability to demonstrate a relationship between this expression and prognostic parameters such as stage and grade in carcinoma cases indicate that it does not play a role in ovarian tumor carcinogenesis. The higher nm 23 expression in advanced stage and less differentiated (with solid and papillary growth pattern) ovarian tumors shows that it behaves like an oncogene in ovarian carcinomas.

\section{REFERENCES}

1. Jemal A, Murray T, Ward E, Samuels A, Tiwari RC, Ghafoor A, Feuer EJ, Thun MJ: Cancer statistics. CA Cancer J Clin 2005, 55:10-30

2. Boyle P, Maisonneuve P, Autier PI: Towards cancer control in women. J Epidemiol Biostat 1998, 3:137-168

3. Kaur TB, Shen T, Gaughan J, Thompson J, Houck KL, Richardson M, Hernandez E: Premalignant lesions in the contralateral ovary of women with unilateral ovarian carcinoma. Gynecol Oncol 2004, 93:69-77

4. Shih I-M, Kurman RJ: Ovarian tumorigenesis- a proposed model based on morphological and molecular genetic analysis. Am J Pathol 2004, 164:1511-518
5. Shimizu Y, Kamoi S, Amada S, Akiyama F, Silverberg SG: Toward the development of a universal grading system forovarian epithelial carcinoma: testing of a proposed system in a series of 461 patients with uniform treatment and follow-up. Cancer 1998, 82:893-901

6. Yoshida K, Miki Y: The cell death machinery governed by the p53 tumor suppressor in response to DNA damage. Cancer Sci 2010, 101:831-835

7. Levine AJ, Moment J, Finlay CA: The p53 tumour suppresor gene. Nature 1991, 351:453-456

8. Werness BA, Freedman AN, Piver MS, Romero-Gutierrez M, Petrow E: Prognostic significance of p53 and p21 immunoreactivity in epithelial cancers of the ovary. Gynecol Oncol 1999, 75:413-418

9. Sagarra RA, Andrade LA, Martinez EZ, Pinto GA, Syrjänen KJ, Derchain SF: p53 and bcl-2 as prognostic predictors in epithelial ovarian cancer. Int J Gynecol Cancer 2002, 12:720-727

10. Kmet LM, Cook LS, Magliocco AM: A review of p53 expression and mutation in human benign, low malignant potential and invasive epithelial ovarian tumors. Cancer 2003, 97:389-404

11. Hockenberry D, Nunez G, Millinan C, Scheriber RD, Korsmeyer SJ: Bcl-2 is an inner mitokondrial membrane protein that blocks programmed cell death. Nature 1990, 348:334-336

12. Mano Y, Kikuchi Y, Yamamoto K, Hirata J, Tode T, Ishii K, Nagata I: $\mathrm{Bcl}-2$ as a predictor of chemosensitivity and prognosis in primary epithelial ovarian cancer. Eur J Cancer 1999, 35: 1214-1219

13. Chan WY, Cheung KK, Schorge JO, Huang LW, Welch WR, Bell DA, Berkowitz RS, Mok SC: Bcl-2 and p53 protein expression, apoptosis and p53 mutation in human epithelial ovarian cancers. Am J Pathol 2000, 156:409-417

14. Geisler JP, Geisler HE, Miller GA, Wiemann MC, Zhou Z, Crabtree W: p53 and bcl-2 in epithelial ovarian carcinoma: their value as prognostic indicators at a median follow-up of 60 months. Gynecol Oncol 2000, 77:278-282

15. Haldar S, Negrini M, Monne M, Sabbioni S, Croce CM: Downregulation of bcl-2 by p53 in human breast cancer cells. Cancer Res 1994, 54:2095-2097

16. Steeg PS, Bevilacqua G, Kopper L, Thorgeirsson UP, Talmadge JE, Liotta LA, Sobel ME: Evidence for a novel gene associated with low tumor metastatic potential. J Natl Cancer Inst 1988, 80:200-204

17. Hartsough MT, Steeg PS: Nm23/nucleoside diphosphate kinase in human cancers. J Bioenerg Biomembr 2000, 32:301-308

18. Scambia G, Ferrandina G, Marone M, Benedetti Panici P, Giannitelli C, Piantelli M, Leone A, Mancuso S: nm23 in ovarian cancer: correlation with clinical outcome and other clinicopathological and biochemical prognostic parameters. J Clin Oncol 1996, 14:334-342

19. Schneider J, Pollán M, Jiménez E, Marenbach K, Martínez N, Volm M, Marx D, Meden H: nm23-H1 expression defines a highrisk subpopulation of patients with early-stage epithelial ovarian carcinoma. Br J Cancer 2000, 82:1662-1670

20. Seidman JD, Russel P, Kurman R: Surface epithelial tumors of the ovary. In: Kurman RJ (Eds): Blaunstein's Pathology of the Female Genital Tract. 5th ed., Newyork, Springer-Verlag, 2002, 791-904 
21. Schuijer M, Berbs E: Tp53 and ovarian cancer. Hum Mut 2003, 21:285-291

22. Wen WH, Reles A, Runnebaum IB, Sullivan-Halley J, Bernstein L, Jones LA, Felix JC, Kreienberg R, el-Naggar A, Press MF: p53 mutations and expression in ovarian cancers: correlation with overall survival. Int J Gynecol Pathol 1999, 18:29-41

23. Skomedal H, Kristensen GB, Abeler VM, Børresen-Dale AL, Tropé C, Holm R: TP53 protein accumulation and gene mutation in relation to overexpression of MDM2 protein in ovarian borderline tumours and stage I carcinomas. J Pathol 1997, 181:158-165

24. Skirnisdottir I, Seidal T, Gerdin E, Sorbe B: The prognostic importance of p53, bcl-2 and bax in early stage epithelial ovarian carcinoma treated with adjuvant chemotherapy. Int J Gynecol Cancer 2002, 12:265-276

25. Inoue M, Fujita M, Enomoto T, Morimoto H, Monden T, Shimano T, Tanizawa O: Immunohistochemical analysis of p53 in gynecologic tumors. Am J Clin Pathol 1994, 102:665-670
26. Diebold J, Baretton G, Felchner M, Meier W, Dopfer K, Schmidt M, Löhrs $\boldsymbol{U}$ : bcl-2 expression, p53 accumulation and apoptosis in ovarian carcinomas. Am J Clin Pathol 1996, 105:341-349

27. Mandai M, Konishi I, Koshiyama M, Mori T, Arao S, Tashiro H, Okamura H, Nomura H, Hiai H, Fukumoto M: Expression and metastasis-related $\mathrm{nm} 23-\mathrm{H} 1$ and $\mathrm{nm} 23-\mathrm{H} 2$ genes in ovarian carcinomas: correlation with clinicopathology, EGFR, c-erbB3 genes and sex steroid receptor expression. Cancer Res 1994, 54:1825-1830

28. Schneider J, Romero H, Ruiz R, Centeno MM, RodriguezEscudero FJ: nm23 expression in advenced and borderline ovarian carcinoma. Anticancer Res 1996, 16:1197-1202

29. Youn BS, Kim DS, Kim JW, Kim YT, Kang S, Cho NH: NM23 as a prognostic biomarker in ovarian serous carcinoma. Mod Pathol 2008, 21:885-892

30. Bai F, Feng J, Cheng Y, Shi J, Yang R, Cui H: Analysis of gene expression patterns of ovarian cancer cell lines with different metastatic potentials. Int J Gynecol Cancer 2006, 16:202-209 